\title{
Micropropagation of Texas Madrone, Arbutus xalapensis H.B.K.
}

\author{
Wayne A. Mackay \\ Texas A\&M University Research and Extension Center, 1380 A\&M Circle, El \\ Paso, TX 79927
}

Additional index words. tissue culture, Ericaceae, Arbutus texana

\begin{abstract}
Mature flowering Arbutus texana trees were successfully micropropagated from shoot tips. Optimum shoot proliferation was achieved on a basal medium consisting of WPM salts, MS vitamins, and sucrose supplemented with 11.1 or $22.2 \mu \mathrm{MBA}$ and no auxin. Microcuttings rooted readily when pulsed with 6.1 $\mu_{\mathrm{M}}$ IBA for 1 week and transferred to auxin-free medium. The addition of charcoal to the rooting medium improved root branching and elongation but suppressed root formation. Chemical names used: $N$ (phenylmethyl)-1H-purin-6-amine (BA); indole-3-butyric acid (IBA).
\end{abstract}

Texas madrone is a small evergreen tree, native to Texas and southern New Mexico, that has potential for urban landscapes in the southwestern United States. A member of the Ericaceae family, it grows equally well on alkaline (pH 7.5-7.8) and slightly acidic soils in central to far West Texas (Simpson, 1988). Trees grow to $12 \mathrm{~m}$ in height with clusters of small, white, lantern-shaped flowers in the spring, followed by yellow-orange to bright red fruit that ripen in the fall, providing visual beauty and food for wildlife. Perhaps the most attractive feature of Texas madrone is the exfoliating bark. Each year, the older bark sloughs off in very thin sheets, exposing new silky smooth bark underneath that varies from pure white to deep reds, with lighter bark colors changing to darker colors as the season progresses.

Texas madrone is propagated from fresh seed collected in the fall. Seed crops must be harvested at optimum ripeness and sown immediately to ensure high percentages of germination (Nokes, 1986). Tipton (1981) successfully rooted cuttings of Texas madrone from nonflowering juvenile stock material. Neither of these methods allows the selection and propagation of superior genotypes since the ornamental characteristics of individual plants are not evident for many years. Other ericaceous plants have been micropropagated successfully (Anderson, 1984; Banko and Stefani, 1989; Isutsa et al., 1994). The present study was initiated to determine if tissue culture techniques could be used to propagate mature Texas madrone, allowing selection of superior genotypes for ornamental landscapes.

Received for publication 22 Apr. 1996. Accepted for publication 13 May 1996. Alejandro Ruiz is thanked for technical assistance. The cost of publishing this paper was defrayed in part by the payment of page charges. Under postal regulations, this paper therefore must be hereby marked advertisement solely to indicate this fact.

\section{Materials and Methods}

Actively growing shoots, $\approx 20 \mathrm{~mm}$ long, were collected from mature trees located at the Texas A\&M Research and Extension Center at El Paso. After leaves were removed, the shoots were trimmed to $\approx 15 \mathrm{~mm}$ in length and surface-disinfested for $15 \mathrm{~min}$ in a continuously stirred $0.5 \%$ sodium hypochlorite solution containing $0.1 \%$ Tween 20 . Shoots were then rinsed three times with sterile distilled water and trimmed to $10 \mathrm{~mm}$ in length and cultured on a basal medium consisting of Woody Plant Medium basal salts (Lloyd and McCown, 1980), 3\% sucrose, MS vitamins (Murashige and Skoog, 1962), and 0.8\% Phytagar (Sigma Chemical Co., St. Louis) supplemented with $11.1 \mu \mathrm{MBA}$. The $\mathrm{pH}$ of the medium was adjusted between 5.7 and 5.8 and the medium dispensed into $55 \times 70$-mm jars (40 ml) capped with polypropylene closures (Magenta B-caps; Magenta Corp., Chicago) before autoclaving at $121 \mathrm{C}, 125 \mathrm{kPa}$ for 20 min. Cultures were grown for 4 weeks at $25 \pm$ $3 \mathrm{C}$ under 16-h photoperiods from cool-white fluorescent lamps $\left(\approx 50 \mu \mathrm{mol} \cdot \mathrm{m}^{-2} \cdot \mathrm{s}^{-1}\right)$. Cultures were subcultured every 4 weeks until sufficient stock was available for experiments.

Shoot proliferation experiments began 5 months after initial establishment. The basal medium was supplemented with BA $(2.2,4.4$, 11.1,22.2, or $44.4 \mu \mathrm{M}$ ) and 1-naphthaleneacetic acid (NAA; $0,0.5$, or $5.4 \mu \mathrm{M}$ ) in factorial combination. Three shoots, $5 \mathrm{~mm}$ long, were placed in each jar with five jars per treatment. Axillary shoots were removed at 5 and 10 weeks and the top $5 \mathrm{~mm}$ of the primary shoot was subcultured on the same medium. Data for main shoot length, number of axillary shoots, and axillary shoot length were collected at 5 , 10 , and 15 weeks and visual ratings were made for callus formation. The experiment was repeated using the same procedures, with the exception that two shoots per jar were cultured.

Rooting was investigated using $\approx 5$-mmlong microcuttings, with at least two nodes below the shoot apex, that were harvested from cultures maintained on basal medium supplemented with 11.1 $\mu \mathrm{MBA}$. Microcuttings were transferred to half-strength basal medium with the following modifications: 1) 6.7 $\mu \mathrm{M}$ NAA, 2) $6.7 \mu \mathrm{M}$ NAA plus activated charcoal at $\left.\left.1 \mathrm{~g} \cdot \mathrm{L}^{-1}, 3\right) 6.1 \mu \mathrm{M} \mathrm{IBA}, 4\right) 6.1 \mu \mathrm{M} \mathrm{IBA}$ plus activated charcoal at $1 \mathrm{~g} \cdot \mathrm{L}^{-1}$, and 5) a control (no auxin). After 1 week on the various media, half of the microcuttings were transferred to half-strength basal medium with no auxin, resulting in nine treatments. Data for the rooting experiment were collected at the end of 4 weeks. Three variables were determined: shoot length, and number and length of roots. The percentages of the microcuttings that rooted were calculated.

All experiments were set up in a completely randomized design and the data were tested by analysis of variance in the General Linear Models procedure (SAS for Windows version 3.1, SAS Institute, Cary N.C.).

\section{Results and Discussion}

Basal medium, containing 11.1 or $22.2 \mu \mathrm{M}$ BA and no NAA, was the optimum for Texas madrone shoot proliferation, producing the desired combination of numerous axillary shoots with satisfactory growth of those shoots (Table 1). Shoot proliferation in Texas madrone responds similarily to that of other ericaceous plants (Banko and Stefani, 1989; Chandler and Draper, 1986; Hosier et al., 1985; Lloyd and McCown, 1980; Lyrene, 1978, 1980; Wolfe et al., 1983) in that NAA at the concentrations tested had a significant negative effect on main shoot length, axillary shoot proliferation, and the mean length of the axillary shoots. Shoots cultured on basal medium supplemented with the same levels of BA combined with $0.54 \mu \mathrm{m}$ NAA produced slightly fewer shoots, although average shoot length was similar to that for the treatments without NAA. Shoots cultured on medium containing 5.4 $\mu \mathrm{M}$ NAA formed callus and roots at all concentrations of BA, with the most callus growth occurring on treatments containing the higher levels of BA. Callus formation increased during subculturing such that during the third subculture period, callus formation was excessive on media supplemented with 5.4 $\mu \mathrm{M}$ NAA. Texas madrone response to BA was similar to that of most other ericaceous plants to micropropagation protocols, with the exception of sourwood [Oxydendron arboreum (L.) DC.], where BA was ineffective for shoot proliferation. Texas madrone differs from blueberries (Vaccinium ashei Reade, V. corymbosum L.) in that it was not necessary to adjust the $\mathrm{pH}$ of the medium downward for successful shoot proliferation (Isutsa et al., 1994; Wolfe et al., 1986). The significance of the main effect of subculture points out that shoot proliferation can be affected by previous subcultures or transfer treatments; thus, effects of subsequent growth regulator treatments may need to be evaluated after one or more subcultures on newly imposed treatments.

While other ericaceous plants have been successfully rooted ex vitro (Banko and Stefani, 1994; Isutsa et al., 1994), my attempts to root Texas madrone microcuttings ex vitro or by 
Table 1. Effect of BA and NAA on main shoot length, number of axillary shoots formed, and the average length of the axillary shoots of Texas madrone shoot cultures after subculture every 5 weeks on Woody Plant Media basal medium.

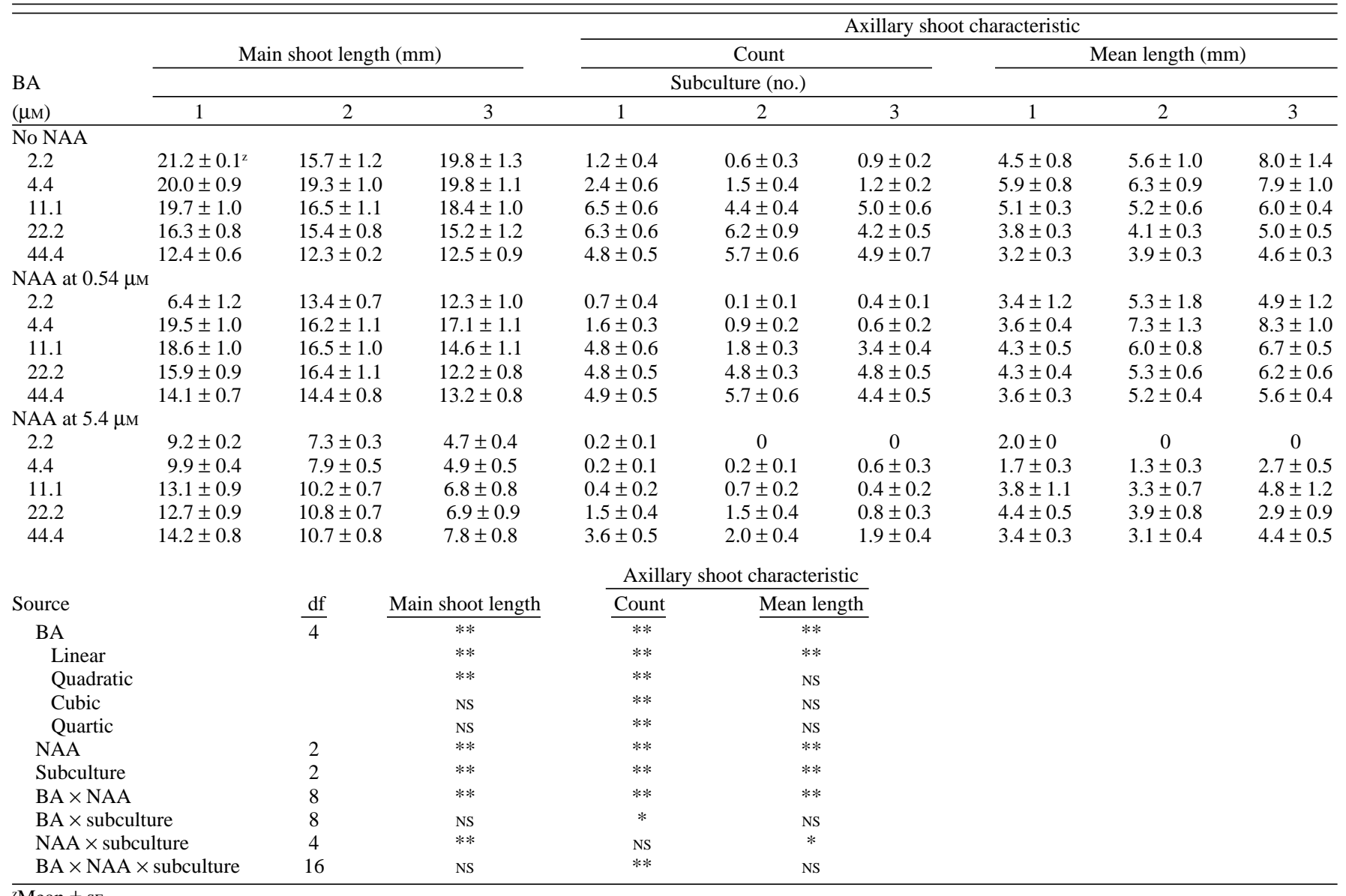

${ }^{2}$ Mean $\pm \mathrm{SE}$

Ns, *, *** Nonsignificant or significant at $P \leq 0.05$ or 0.01 , respectively.

pulsing the microcuttings in vitro and then transferring them to ex vitro rooting medium were unsuccessful (data not shown). However, $83 \%$ of the Texas madrone microcuttings rooted within 4 weeks in vitro when placed on medium supplemented with $6.1 \mu \mathrm{M}$ IBA without charcoal and then transferred to auxin-free medium. On medium supplemented with 6.7 $\mu_{\mathrm{M}}$ NAA, without charcoal, $77 \%$ of the microcuttings rooted when transferred to auxinfree medium. The average number of roots formed per microcutting in these two treatments were similar, 2.7 and 2.6, respectively. Charcoal significantly reduced root count and rooting percentages $(P \leq 0.001)$. Those microcuttings that were not transferred to auxin-free medium formed an excessive amount of callus and the roots were poorly attached to the stems. The best quality roots were those produced in the transfer treatments or on medium with charcoal. These roots were thin, white, and branched, while those on continuous exposure to either NAA or IBA were short and dark. I conclude that pulsing shoots with auxin in vitro is the best method for rooting microcuttings of Texas madrone.

The results with the clone used in this study, and two other clones using the protocol described, suggest that micropropagation is an alternative to present commercial propagation practices that will allow the introduction of superior Texas madrone individuals into the nursery trade.

\section{Literature Cited}

Anderson, W.C. 1984. A revised tissue culture medium for shoot proliferation of rhododendron. J. Amer. Soc. Hort. Sci. 109:343-347.

Banko, T.J. and M.A. Stefani. 1989. In vitro propagation of Oxydendron arboreum from mature trees. HortScience 24:683-685.

Chandler, C.K. and A.D. Draper. 1986. Effect of zeatin and 2ip on shoot proliferation of three highbush blueberry clones in vitro. HortScience 21:1065-1066.

Hosier, M.A., G. Flatebo, and P.E. Read. 1985. In vitro propagation of lingonberry. HortScience 20:364-365.

Isutsa, D.K., M.P. Pitts, and K.W. Mudge. 1994. Rapid propagation of blueberry plants using ex vitro rooting and controlled acclimatization of micropropagules. HortScience 29:1124-1126.

Lloyd, G.B. and B.H. McCown. 1980. Commercially-feasible micropropagation of mountain laurel, Kalmia latifolia by use of shoot-tip culture. Proc. Intl. Plant Prop. Soc. 30:421-427.

Lyrene, P.M. 1978. Blueberry callus and shoot-tip culture. Proc. Fla. State Hort. Soc. 91:171-172.

Lyrene, P.M. 1980. Micropropagation of rabbiteye blueberries. HortScience 15:80-81.

Murashige, T. and F. Skoog. 1962. A revised medium for rapid growth and bioassays with tobacco cultures. Physiol. Plant. 15:473-497.

Nokes, J. 1986. How to grow native plants of Texas and the southwest. Texas Monthly Press, Austin.

Simpson, B.J. 1988. A field guide to Texas trees. Texas Monthly Press, Austin.

Tipton, J.L. 1981. Asexual propagation of juvenile Arbutus xalapensis in a high humidity chamber. Plant Propagator 27:11-12.

Wolfe, D.E., C. Chin, and P. Eck. 1986. Relationship of the pH of medium to growth of 'Bluecrop' highbush blueberry in vitro. HortScience 21:296298.

Wolfe, D.E., P. Eck, and C. Chin. 1983. Evaluation of seven media for micropropagation of highbush blueberry. HortScience 18:703-705. 